\title{
Lactose crystallisation and early Maillard reaction in skim milk powder and whey protein concentrates
}

\author{
François MORGAN, Corinne APPOLONIA NOUZILLE, Robert BAECHLER, \\ Gilles VUATAZ*, Alois RAEMY \\ Nestlé Research Center, Nestec Ltd., Vers-chez-les-Blanc, CH-1000 Lausanne 26, Switzerland
}

Published online 12 July 2005

\begin{abstract}
Lactose crystallisation and Maillard reaction are two major modifications occurring in milk and whey powders during processing and storage. In this work, the aim was first to monitor the solid-state early Maillard reaction (EMR) in whey protein concentrates (WPC) heated at $60{ }^{\circ} \mathrm{C}$ and various water activities, and then, to characterise the physical changes that occur as a consequence of heat treatment in skim milk powder (SMP) and WPCs. After $\mathrm{a}_{\mathrm{w}}$ adjustment, SMP and WPC were heated at $60^{\circ} \mathrm{C}$ in hermetic conditions to induce an amino-sugar reaction. Furosine analysis (\% of blocked lysine) was used to monitor the progress of EMR. The results showed that the kinetic of EMR was linked to the initial $\mathrm{a}_{\mathrm{w}}$ of the powders. Heating of SMP may lead to the crystallisation of lactose in humidified powders, without apparently affecting the progress of EMR. Surprisingly, lactose crystallisation - monitored by micro-Differential Scanning Calorimetry - was easily induced in heated SMP, whereas it was delayed or even inhibited in WPC. The results showed that this effect was dependent on the protein/lactose ratio in WPCs.
\end{abstract}

lactose crystallisation / early Maillard reaction / whey protein concentrate / water activity

Résumé - Cristallisation du lactose et réaction de Maillard précoce dans les poudres de lait écrémé et les concentrés de protéines du lactosérum. La cristallisation du lactose et la réaction de Maillard sont deux modifications importantes survenant au cours de la production et du stockage des poudres de lait et de lactosérum. L'objectif de ce travail était dans un premier temps de suivre la réaction de Maillard précoce (RMP) dans des concentrés de protéines de lactosérum (CPL) chauffés à $60^{\circ} \mathrm{C}$ à différentes activités d'eau et, dans un deuxième temps, de caractériser les modifications physiques consécutives au traitement thermique (comparaison poudres de lait écrémé et CPL). Les poudres de lait écrémé et les CPL - équilibrés à différentes activités d'eau - étaient chauffés à $60{ }^{\circ} \mathrm{C}$ dans des conditions hermétiques pour induire la RMP (suivie par l'analyse de la furosine). Les résultats indiquaient que la cinétique de la RMP était liée à l'activité d'eau initiale de poudres. Dans les poudres de lait écrémé humidifiées et chauffées, la cristallisation du lactose ne semblait pas avoir d'impact sur l'évolution de la RMP. La microcalorimétrie différentielle à balayage permettait d'observer que la cristallisation du lactose, induite facilement dans les poudres de lait écrémé, était retardée voire inhibée dans les CPL. Les résultats indiquent que cet effet était dépendant du rapport protéine/lactose dans les CPL.

cristallisation du lactose / réaction de Maillard précoce / concentré de protéines du lactosérum / activité de l'eau

\footnotetext{
* Corresponding author: gilles.vuataz@rdls.nestle.com
} 


\section{INTRODUCTION}

Whey protein concentrates (WPCs) are produced from cheese whey or from milk microfiltrate by ultrafiltration and spray drying. As a function of the ultrafiltration step, lactose content in powdered WPCs varies from $51 \%$ to $5 \%$ and, consequently, protein content varies from $35 \%$ to $80 \%$. During the processing and storage of WPCs, lactose might be involved in various modifications, e.g. chemical modifications such as early Maillard reaction (EMR) where lactose reacts with free aminogroups of proteins, or physical modifications such as lactose crystallisation where lactose interacts with itself to induce nucleation and crystal formation.

The nature and extent of the Maillard reaction depend on numerous factors, including water activity $\left(\mathrm{a}_{\mathrm{w}}\right), \mathrm{pH}$, temperature and the physico-chemical state of the components. Numerous published results have shown that EMR can progress with a very high rate in a powdered matrix with intermediate $\mathrm{a}_{\mathrm{w}}(0.3-0.7)$. Model studies on the solid-state EMR between the main whey protein, $\beta$-lactoglobulin $(\beta-\mathrm{LG})$ and lactose have shown that the rate of Maillard reaction is accelerated at intermediate water activity and have provided a very extensive characterisation of glycoconjugates [1315]. These studies demonstrated that extensively lactosylated $\beta$-LG - obtained after a dry heating $\left(50{ }^{\circ} \mathrm{C}\right)$ of powder under a relative humidity of $65 \%$ - was more structurally stable than $\beta$-LG reacted with lactose in an aqueous solution. However, the impacts of water activity and glass transition were not properly addressed in these studies.

Physical modifications of amorphous dairy powders have been extensively studied, most of the work being conducted on milk powders and whey powders, which leads to a lack of data for WPCs. The understanding of the physical behaviour of milk powders has markedly increased during recent years, and useful tools such as the milk state diagram have been developed [8, $11,19]$. The link between physical state and Maillard browning (which does not account for EMR only) has been demonstrated in various dehydrated model systems [9, 12], milk powders $[16,19]$ and whey powders $[2,10,17]$. Numerous authors have shown that the crystallisation of amorphous lactose in dairy and whey powders is controlled by the temperature difference between storage temperature and glass transition temperature (Tg). Jouppila and Roos [7] have observed on milk powders that lactose crystallisation was affected by the presence of milk proteins (when compared with pure lactose). Burin et al. [2] have shown that besides physical parameters, the composition of whey models plays a role in their propensity to undergo Maillard reactions. Recent data have been focused on the role of protein content and structure on the crystallisation of lactose in amorphous materials. For instance, in spray-dried lactose/ protein mixtures, Haque and Roos [6] have shown that lactose crystallisation was delayed by the presence of proteins. The type of proteins also had an impact on the delay of crystallisation, and the proposed mechanism for such an effect was attributed to differences in the miscibility properties of proteins with sugars in the dry state. Thomas et al. [18] have studied lactose crystallisation in freeze-dried powders with $\beta$-LG and lactose. They found that lactose/ $\beta$-LG interactions stabilised freeze-dried powders against lactose crystallisation. They proposed that the spatial organisation of proteins within the powder particle might account for this effect. Non-covalent interactions between protein and sugars in the dry state are known to occur via hydrogen bonding [3], and these interactions could also have an impact on the propensity of lactose to crystallise.

Our objectives in this work were first to monitor the EMR in WPCs heated a mild temperature $\left(60{ }^{\circ} \mathrm{C}\right)$ and various water activities. A second objective was to evaluate how physical changes that occur as a consequence of the mild heat treatment (glass transition, lactose crystallisation and water activity change) could impact the rate of EMR in skim milk powder (SMP) and WPCs. Finally, the crystallisation of lactose in WPCs was compared with that of SMP, using micro-Differential Scanning Calorimetry (micro-DSC). 
Table I. Water activities and water contents of SMPs and WPCs at initial water activity (*) and after water sorption with saturated salts. Two batches of SMP powders with different initial water activities were used, and one batch was further humidified.

\begin{tabular}{llc}
\hline $\begin{array}{l}\text { Sample } \\
\text { (protein/lactose content in \% wet basis) }\end{array}$ & $\mathrm{a}_{\mathrm{w}}$ & Water content (\%) \\
\hline SMP & $0.211^{*}$ & n.d. \\
$(35 / 51)$ & $0.278^{*}$ & 5.33 \\
& 0.373 & n.d. \\
& & \\
WPC 35 & $0.233^{*}$ & 4.09 \\
$(35 / 51)$ & 0.291 & 5.27 \\
& 0.363 & 6.78 \\
WPC 60 & $0.258^{*}$ & 5.64 \\
$(60 / 23)$ & 0.339 & 6.66 \\
& 0.498 & 9.15 \\
\hline
\end{tabular}

\section{MATERIALS AND METHODS}

\subsection{Milk and whey powders}

WPCs (Lacprodan 35 and Lacprodan 60) were purchased from Arla Foods (Viby, Denmark). The SMP was provided by Nestlé (Konolfingen, Switzerland). Humidification of the powders was conducted in closed chambers with saturated salts. The salts used were $\mathrm{MgCl}_{2} \quad\left(\mathrm{a}_{\mathrm{w}}=0.33\right), \mathrm{K}_{2} \mathrm{CO}_{3}$ $\left(\mathrm{a}_{\mathrm{w}}=0.44\right)$ and $\mathrm{MgNO}_{3}\left(\mathrm{a}_{\mathrm{w}}=0.53\right)$. Water uptake was monitored during this phase (4 to 14 days) and the powders were then placed in sealed opaque aluminium bags. Actual water activities might be slightly different than those corresponding to the saturated salts (sorption stopped before equilibrium). The powders were then kept (at least for 1 week) in sealed opaque aluminium bags at $20^{\circ} \mathrm{C}$ for equilibration of water within the matrix. Water activity was then controlled before powder handling (see Sect. 2.3). The state of lactose in all powders was found to be amorphous after water sorption and equilibration (Microscopy and Near-Infrared Reflectance spectrometry).

Early Maillard reaction was induced by a heat treatment of the powders at $60{ }^{\circ} \mathrm{C}$ for up to $450 \mathrm{~min}$, in hermetic screw-capped metallic tubes, using a home-made heating apparatus. The measured temperature reached $60^{\circ} \mathrm{C} \pm 1^{\circ} \mathrm{C}$ in the powders in less than $2 \mathrm{~min}$.

\subsection{Furosine analysis by amino acid analyser}

Lysine and furosine in acid hydrolysates of proteins were separated by cation exchange chromatography and quantified by comparison with an external standard after derivatisation with ninhydrin and spectrophotometric detection, as described in Fenaille et al. [4]. The percentage of blocked lysine is calculated assuming that during hydrolysis about $40 \%$ of $\varepsilon$-deoxy-fructose-lysine is retransformed into lysine, part is transformed into pyridosine and about $32 \%$ into furosine [5].

\subsection{Water activity}

Measurements of $\mathrm{a}_{\mathrm{w}}$ were carried out at $25{ }^{\circ} \mathrm{C}$ with a Hygroskop model DT instrument (Rotronic, Bassersdorf, Germany), based on the official AOAC method 978.18 [1]. All water activity values were corrected with respect to $a_{w}$ values obtained with 5 standard saturated salts $\left(\mathrm{a}_{\mathrm{w}}: 0.111,0.225\right.$, $0.328,0.432$ and 0.529$)$.

\subsection{Water content: $\mathrm{P}_{\mathbf{2}} \mathrm{O}_{\mathbf{5}}$ method}

A certain amount of powder (around $2 \mathrm{~g}$ ) was placed on pans inside a glass tube containing $\mathrm{P}_{2} \mathrm{O}_{5}$. Pressure was reduced in the 

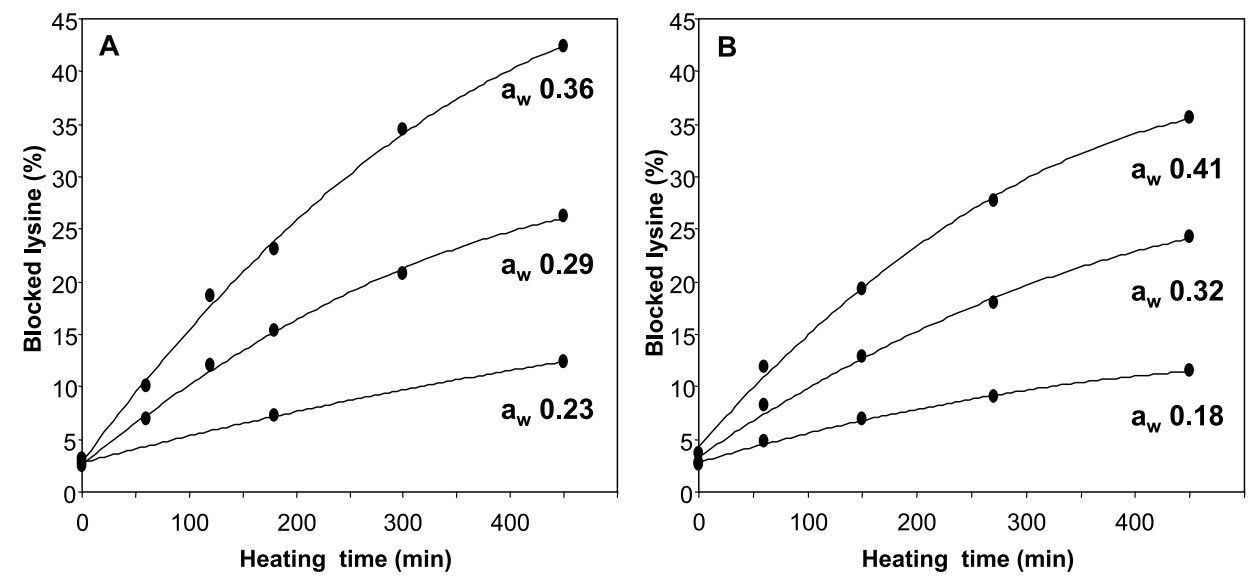

Figure 1. Evolution of blocked lysine during heat treatment at $60{ }^{\circ} \mathrm{C}$ of WPC35 (A) and WPC60 (B) having various water activities.

glass tubes using a vacuum at $26.6 \times 10^{2} \mathrm{~Pa}$ for around $20 \mathrm{~s}$. Then they were placed in the oven and heated at $102{ }^{\circ} \mathrm{C}$ for $2 \mathrm{~h}$ and then left to cool down for $45 \mathrm{~min}$. The vacuum was broken and the sample was weighed. Based on the weight differences, the amount of water loss was measured.

\subsection{Microscopic examination of the lactose crystallisation state}

The presence or absence of lactose crystals was determined by direct microscopic observation of the powders under polarised light, using a Wild Heerbrugg microscope (Leica microsystems, Glattbrugg, Switzerland). This method did not give quantitative results.

\subsection{Near-Infrared Reflectance spectrometry}

Samples were scanned using an InfraAnalyzer 500 scanning NIR spectrometer (Bran \& Luebbe, Norderstedt, Germany). The instrument scans from 1400 to $2400 \mathrm{~nm}$ with a resolution of $4 \mathrm{~nm}$, using an integrating sphere (reflectance mode) and a lead sulphide detector. The measurements took place in a closed cell through a quartz window.

All NIR spectra were output as JCAMP format from the instrument and converted into absorption values corresponding to each peak using a home-made program. Further, these absorption values were normalised to eliminate the texture effects. Normalisation was performed using Microsoft Excel by a first-order transformation with two fixed points at 1680 and $2232 \mathrm{~nm}$ (0.359 and 0.688 absorbance, respectively). The selected range of wavelengths (1650 to $2250 \mathrm{~nm}$ ) contains peaks directly proportional to the water content $(1940 \mathrm{~nm})$ and crystallised carbohydrate $(2100 \mathrm{~nm})$.

\subsection{Micro-Differential Scanning Calorimetry}

The Micro-DSC III from the company Setaram (Caluire, France) was used at $0.1{ }^{\circ} \mathrm{C} \cdot \mathrm{min}^{-1}$. Temperature was scanned between $10^{\circ} \mathrm{C}$ and $120^{\circ} \mathrm{C}$. Sample weights were about $100 \mathrm{mg}$. Reference material was $\mathrm{Al}_{2} \mathrm{O}_{3}$.

\section{RESULTS}

\subsection{Early Maillard reaction in whey and milk powders}

Figure 1 shows the progress of EMR in WPCs as a function of water activity and heating time. As expected, EMR was accelerated when water activity increased from 
0.23 to 0.36 for WPC 35 and from 0.18 to 0.41 for WPC60, as a result of a lower glass transition temperature ( $\mathrm{Tg}$ ) and increased molecular mobility of reactants $[2,9,16]$.

The results in Figure 1 show that EMR was faster in WPC35 (Fig. 1A, $\mathrm{a}_{\mathrm{w}} 0.29$ and 0.36 ) than in WPC60 (Fig. 1B, at slightly higher corresponding $\mathrm{a}_{\mathrm{w}}$ ). This experiment was not repeated; however, in all our experiments on WPCs, a general trend was that the rate of EMR was higher in lactose-rich WPCs (WPC35 and WPC50) than in lowlactose WPCs (WPC60, WPC75 and WPC80). This could be due to a limiting number of free lactose molecules available for each protein monomer in low-lactose WPCs. The importance of the composition of whey systems on the rate of Maillard reaction has been previously highlighted by Burin et al. [2]. Moreover, the $\mathrm{Tg} / \mathrm{a}_{\mathrm{w}}$ relationship slightly differs according to the protein/lactose contents in WPCs (unpublished data). For instance, at a similar $\mathrm{a}_{\mathrm{w}}$, the Tg of WPC 60 was ca. $2-5{ }^{\circ} \mathrm{C}$ higher than that of WPC 35 , hence the molecular mobility during heating at $60{ }^{\circ} \mathrm{C}$ would be lower in WPC60 than in WPC35.

Then, the next step was to compare the chemical reactivity of proteins in WPC and SMP. For that purpose, WPC35 and SMP were heated in sealed tubes at $60^{\circ} \mathrm{C}$ at similar water activities $(0.36$ and 0.37 , respectively) to induce EMR. WPC35 was chosen for this experiment since it contains the same amounts of protein and lactose as SMP (35\% protein, $51 \%$ lactose). The results shown in Figure 2B indicate that the development of EMR was similar for both WPC35 and SMP, except at prolonged heating times ( $>300 \mathrm{~min})$ where a break in the progress of the amino-sugar reaction was measured for SMP. For similar $\mathrm{a}_{\mathrm{w}}$, the $\mathrm{Tg}$ of WPC 35 was ca. $4-5^{\circ} \mathrm{C}$ higher than for SMP (unpublished results), hence the molecular mobility during heating at $60{ }^{\circ} \mathrm{C}$ would be slightly lower in WPC than in SMP.

Figure $2 \mathrm{~A}$ shows that after $60 \mathrm{~min}$ of heating SMP at $60{ }^{\circ} \mathrm{C}, \mathrm{a}_{\mathrm{w}}$ increased drastically from 0.37 to reach 0.50 after $120 \mathrm{~min}$ and 0.55 after $300 \mathrm{~min}$. This was the consequence of lactose crystallisation, which was evidenced by microscopy and NIR

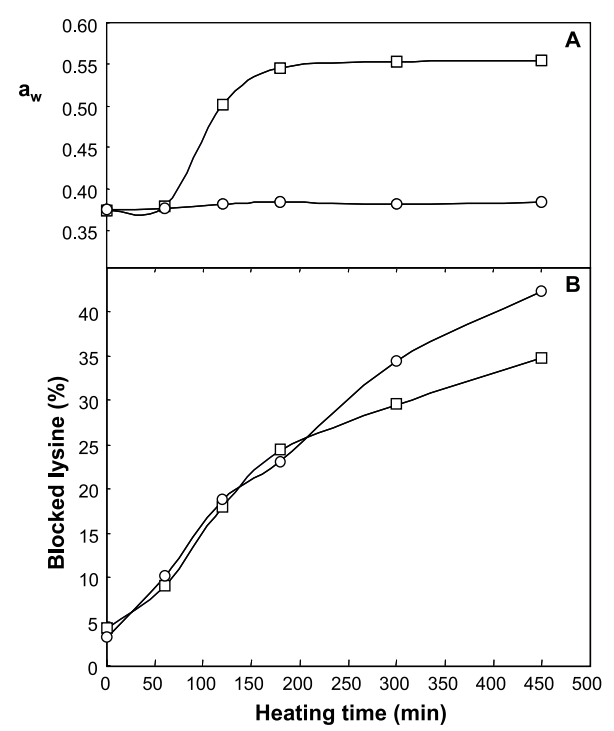

Figure 2. Evolution of water activity (A) and blocked lysine (B) during heat treatment at $60{ }^{\circ} \mathrm{C}$ of SMP (squares) at initial aw 0.37 and WPC 35 (circles) at initial $\mathrm{a}_{\mathrm{w}} 0.36$.

(data not shown). As previously reported by others there is a clear correlation between the extent of lactose crystallisation and the evolution of $\mathrm{a}_{\mathrm{w}}$ of SMP. The two phenomena are linked since water is released upon lactose crystallisation. The water arising from lactose crystallisation remains in the matrix (sealed tubes, the water content did not change) and increases the overall $\mathrm{a}_{\mathrm{w}}$ of the system. This should not occur with an open system [10].

In SMP, the increase in $\mathrm{a}_{\mathrm{w}}$ during heat treatment had no apparent effect on the chemical reactivity of proteins. It is possible that the reorganisation of water molecules after crystallisation did not lead to an increase in the molecular mobility of reactants. On the other hand, crystallised lactose is no longer available for reaction with proteins, and this could cause a limitation of the reaction rate.

Surprisingly, lactose crystallisation was not observed in WPC35 during and after the heat treatment, and this behaviour was remarkably different to that of lactose in SMP. This experiment was not repeated 


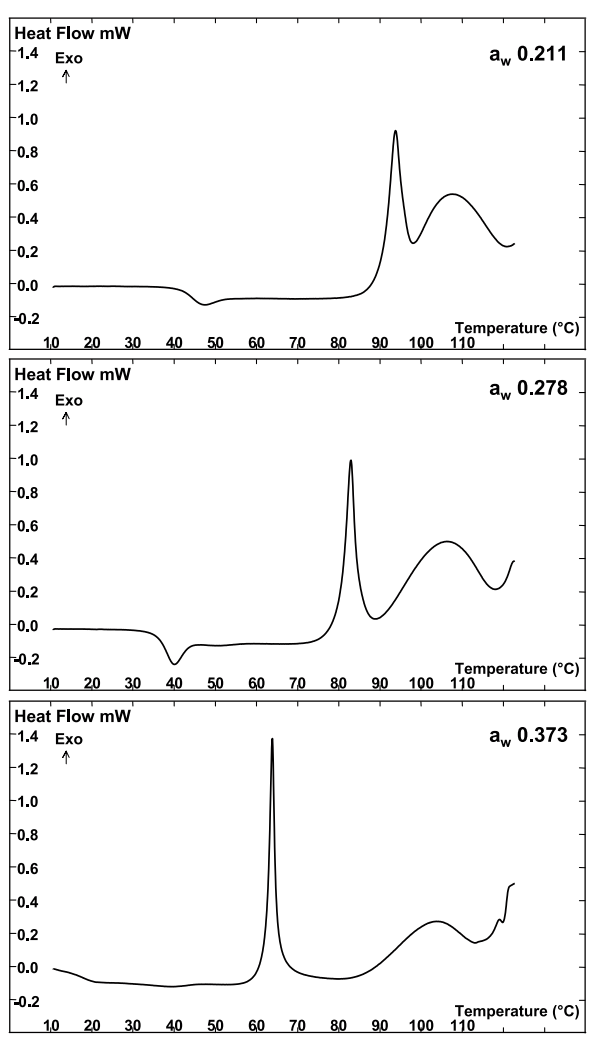

Figure 3. Micro-DSC curves obtained for SMP at three water activities.

with exactly the same values of $a_{w}$. However, we failed to induce lactose crystallisation in all our experiments on WPC 35 equilibrated at $\mathrm{a}_{\mathrm{w}}$ between 0.2 and 0.5 and heated at $60{ }^{\circ} \mathrm{C}$ for up to $8 \mathrm{~h}$.

Further experiments using micro-DSC were then carried out for a better understanding of lactose crystallisation in SMP and WPCs.

\subsection{Lactose crystallisation in SMP}

For SMP at three water activities (Fig. 3) the interpretation of the calorimetric curve is easy: we observed glass transition, lactose crystallisation (onset between 62 and $90{ }^{\circ} \mathrm{C}$ according to $\mathrm{a}_{\mathrm{w}}$ ) and Maillard reaction at higher temperatures. The superimposed curves clearly indicate the effect of

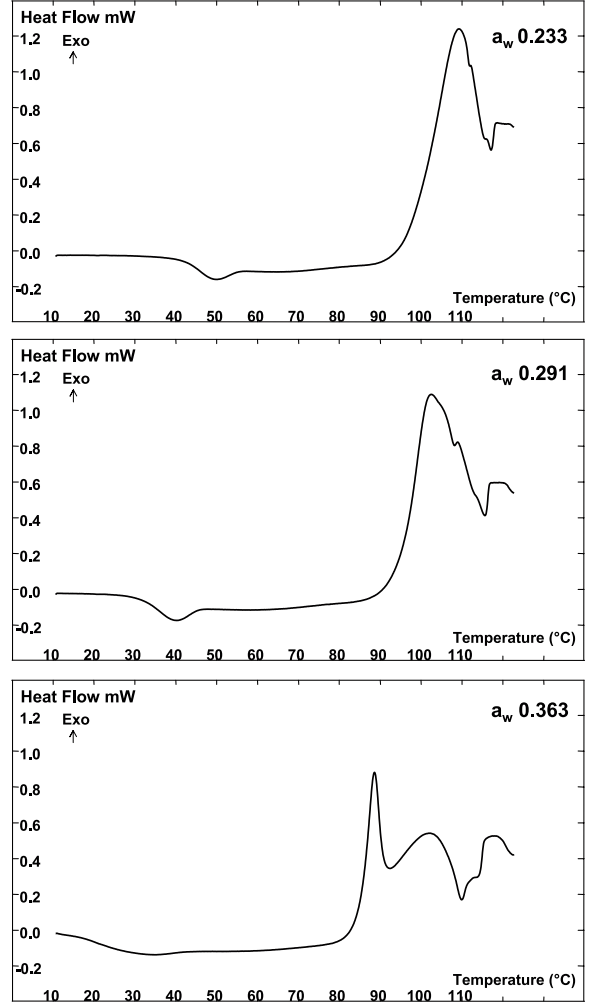

Figure 4. Micro-DSC curves obtained for WPC 35 at three water activities.

$\mathrm{a}_{\mathrm{w}}$ : glass transition, lactose crystallisation and Maillard reactions' temperature ranges decrease drastically with an increase in $\mathrm{a}_{\mathrm{w}}$.

\subsection{Lactose crystallisation in WPCs}

For the WPC35 (Fig. 4), the increase in $\mathrm{a}_{\mathrm{w}}$ leads to a temperature decrease in all the exothermic phenomena (Maillard browning and glass transition). For the WPC sample at the highest $\mathrm{a}_{\mathrm{w}}\left(\mathrm{a}_{\mathrm{w}} 0.363\right.$, water content: $6.78 \%$ ), crystallisation was eventually observed as an exothermic peak below Maillard reaction. In order to verify whether this exothermic peak observed on the WPC 35 at $\mathrm{a}_{\mathrm{w}} 0.363$ was due to lactose crystallisation, a second micro-DSC run was performed and the analysis was stopped at $92{ }^{\circ} \mathrm{C}$ (just after the exothermic peak) and 


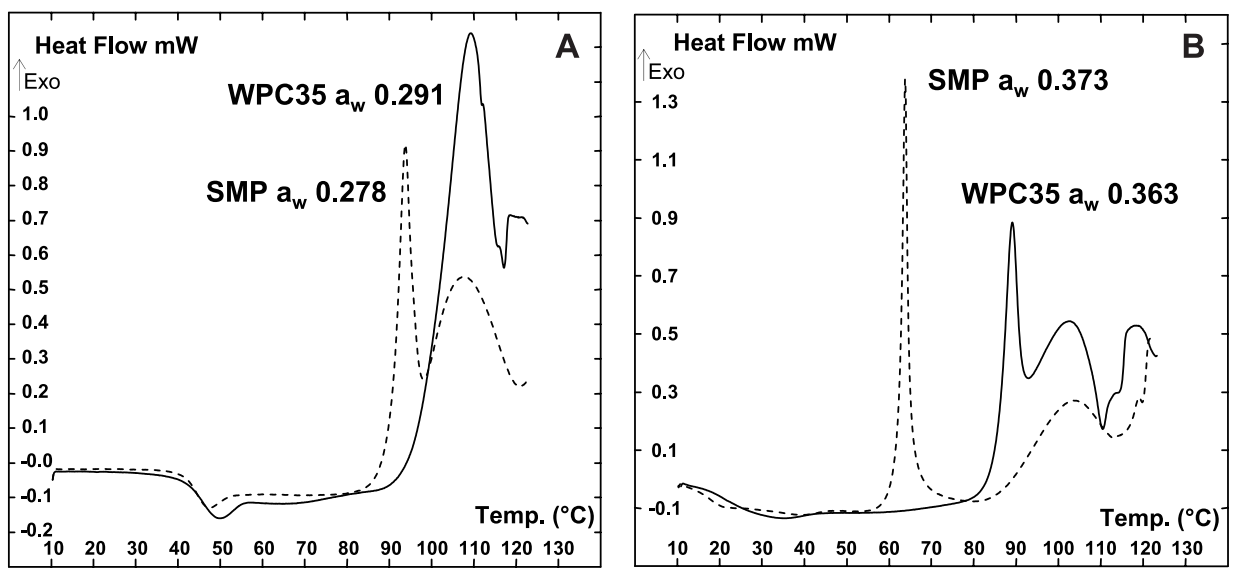

Figure 5. Superimposed Micro-DSC curves obtained for WPC35 (continuous line) and SMP (dotted line) at similar water activities.

the sample removed from the DSC apparatus. The physical state of lactose was then observed by microscopic observation and NIR spectroscopy. NIR experiments clearly showed the sample contained a significant amount of lactose crystals, mainly in the $\alpha$ form. Lactose crystals were also observed by microscopic observation of the sample under polarised light.

Figure 5 shows superimposed DSC curves obtained for WPC 35 and SMP equilibrated at similar $\mathrm{a}_{\mathrm{w}}$. As stated earlier, for similar $\mathrm{a}_{\mathrm{w}}$, the Tg of WPC 35 was ca. $4-5{ }^{\circ} \mathrm{C}$ higher than that of SMP (unpublished results), hence the molecular mobility during heating at $60^{\circ} \mathrm{C}$ would be slightly lower in WPC than in SMP.

The onset of exotherms corresponding to Maillard browning was not different in WPC35 and SMP. On the contrary, the onset of the exotherm corresponding to lactose crystallisation was shifted to higher temperatures at high $\mathrm{a}_{\mathrm{w}}$, and was not observed at low $\mathrm{a}_{\mathrm{w}}$ for WPC 35 while it was clearly identified in SMP for both $\mathrm{a}_{\mathrm{w}}$.

For the WPC60 (Fig. 6), two exotherms were observed as for WPC 35, but the two phenomena were less separated. The $a_{w}$ increase leads to a slight reduction of both temperature and intensity of the exothermic peaks. The lower impact of $\mathrm{a}_{\mathrm{w}}$ on the calorimetric behaviour of WPC60 compared with WPC35 might be due to a quite low lactose

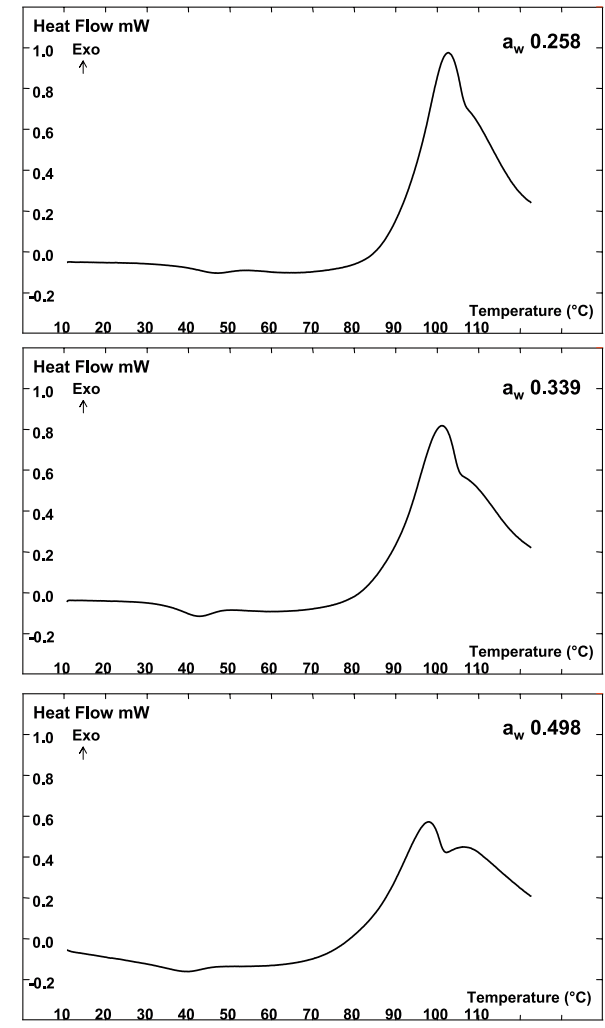

Figure 6. Micro-DSC curves obtained for WPC60 at three water activities. 
concentration in the WPC60 (23\% compared with $51 \%$ in WPC 35). The occurrence of lactose crystallisation in WPC60 was checked on a sample with the highest $\mathrm{a}_{\mathrm{w}}\left(\mathrm{a}_{\mathrm{w}} 0.498\right.$, water content: $\left.9.15 \%\right)$, after having stopped the DSC experiments at $95^{\circ} \mathrm{C}$ (first exotherm) and $120^{\circ} \mathrm{C}$ (second exotherm). The powders were removed from the DSC apparatus and then submitted to NIR analysis and microscopic observation. Lactose crystallisation was not observed by NIR in the "stopped" samples at $95{ }^{\circ} \mathrm{C}$ and $120^{\circ} \mathrm{C}$ and no lactose crystals were seen by microscopic observation under polarised light. This suggested that lactose crystallisation was completely inhibited in WPC60, even if treated in extreme conditions (i.e. 10 to $120{ }^{\circ} \mathrm{C}$ for $1100 \mathrm{~min}$ at $\mathrm{a}_{\mathrm{w}} 0.498$ ). Consequently, the two exotherms observed for WPC60 were probably due to different stages of advanced Maillard reactions.

\section{DISCUSSION}

This study showed that the rate of solidstate EMR in whey protein concentrates heated at $60{ }^{\circ} \mathrm{C}$ is strongly dependent on $\mathrm{a}_{\mathrm{w}}$. However, the progress of EMR is also dependent on the protein/lactose ratio initially present in WPC: WPC35 (with $35 \%$ protein and $51 \%$ lactose) reacted faster than WPC60 (with $60 \%$ protein and $23 \%$ lactose). These results were in accordance with the study by Burin et al. [2], where the rate of Maillard browning followed the order sweet whey powders $>$ WPC $>$ whey protein isolate. This was related to the differences in the content of lactose in these powders.

Then, we compared the reactivity of WPC 35 and SMP (same protein and lactose contents) upon solid-state heating $\left(60^{\circ} \mathrm{C}\right.$, at $\mathrm{a}_{\mathrm{w}} 0.36$ and 0.37 for WPC35 and SMP, respectively). The results showed that the chemical reactivity (i.e. rate of EMR) is similar, whereas the physical behaviour of these two powders is totally different. During mild heating $\left(60^{\circ} \mathrm{C}\right)$ of humidified SMP $\left(\mathrm{a}_{\mathrm{w}}\right.$ 0.37), lactose crystallisation occurs after a delay (ca. $2 \mathrm{~h}$ ), and this leads to a drastic increase in water activity. On the contrary, lactose does not crystallise in
WPC 35 heated in similar conditions of temperature and $\mathrm{a}_{\mathrm{w}}$.

The occurrence and onset of lactose crystallisation in WPCs and SMP were further studied by micro-DSC. The results clearly showed that lactose crystallisation is delayed in WPC35 compared with SMP and is totally inhibited in WPC60. Several hypotheses might explain this result. Thomas et al. [18] have found that the presence of $\beta$-LG (the main whey protein) induces a delay in the crystallisation of lactose in freeze-dried powders ( 2 different powders were used with protein/lactose ratios of 10/ 90 and 40/60). They proposed that the spatial organisation of proteins might account for this effect, since $\beta$-LG might be located on the surface of powder particles and might thus limit the access of water to amorphous lactose. However, this does not explain the differences observed between the behaviour of lactose in WPC and SMP.

Haque and Roos [6] have shown that lactose crystallisation was delayed in spraydried protein powders, but that the delay was less in whey protein powders compared with caseinate, albumin or gelatine. The authors proposed that the miscibility of sugar and proteins might account for these differences, and that whey proteins and lactose might be phase separated. More experiments are needed to evaluate this hypothesis. There is an apparent contradiction between this study and our results, since Haque and Roos [6] showed that whey proteins were less efficient than caseinate at delaying lactose crystallisation. However, in our study we compared whey protein powders with skim milk powders, and not with caseinate powders; the casein in these two powders has a totally different structure: i.e. casein micelles in SMP vs. random coil dissociated proteins in caseinate.

We propose that in WPC, the crystallisation of lactose is delayed due to molecular interactions between lactose and proteins. Carpenter and Crowe [3] have shown that in the dry state, sugars interact with polar groups of globular proteins via hydrogen bonding. The competition between whey proteins/lactose interactions (hydrogen bonds) and lactose/lactose interactions (nucleation) might therefore reduce the propensity of 
lactose to crystallise. Protein/sugar hydrogen bonding might be more intense in whey protein powders (soluble proteins with exposed polar groups) than in skim milk powders containing casein micelles.

Besides protein/lactose interactions, the presence of minerals and ions (with equilibrium between the bound and free form highly different in WPC and in SMP) might also impact the crystallisation of lactose, but this was not addressed in the present study.

\section{CONCLUSION}

These results help to understand the role played by protein structures and protein/ sugar interactions in the physical stability of dairy powders and ingredients. We have shown that whey proteins can inhibit or delay the crystallisation of lactose in WPCs. Molecular interaction between whey proteins and lactose through hydrogen bonding is likely to be responsible for this anti-crystallisation effect. The next step will be to study the physical behaviour of spray-dried powders, with a focus on the impact of whey protein structure in WPCs, and on the impact of a varying ratio of casein micelles to whey proteins in SMPs. In our future experiments, a careful control of $\mathrm{Tg}$ will also be needed to fully elucidate the links between composition and physical properties of powders.

\section{REFERENCES}

[1] AOAC, Official Methods of Analysis of AOAC International, 16th edn., AOAC International, Arlington, VA, 1995.

[2] Burin L., Jouppila K., Roos Y., Kansikas J., Buera M.P., Color formation in dehydrated modified whey powder systems as affected by compression and Tg, J. Agric. Food Chem. 48 (2000) 5263-5268.

[3] Carpenter J.F., Crowe J.H., An infrared spectroscopic study of the interactions of carbohydrates with dried proteins, Biochemistry 28 (1989) 3916-3922.

[4] Fenaille F., Campos Giménez E., Guy P.A., Schmitt C., Morgan F., Monitoring of $\beta$-Lactoglobulin dry-state glycation using various analytical techniques, Anal. Biochem. 320 (2003) 144-148.

[5] Finot P.A., Deutsch R., Bujard E., The extent of Maillard reaction during the processing of milk, Prog. Food Nutr. Sci. 5 (1981) 345-355.
[6] Haque K., Roos Y.H., Water plasticization and crystallization of lactose in spray-dried lactose/protein mixtures, J. Food Sci. 69 (2004) 23-29.

[7] Jouppila K., Roos Y.H., Glass transitions and crystallization in milk powders, J. Dairy Sci. 77 (1994) 2907-2915.

[8] Jouppila K., Kansiskas J., Roos Y.H., Glass transition, water plasticization, and lactose crystallization in skim milk powder, J. Dairy Sci. 80 (1997) 3152-3160.

[9] Karmas R., Buera M.P., Karel M., Effect of glass transition on rates of nonenzymatic browning in food systems, J. Agric. Food Chem. 49 (1992) 4706-4712.

[10] Kim M.N.M., Saltmarch M., Labuza T.P., Nonenzymatic browning of hygroscopic whey powders in open versus sealed pouches, J. Food Process. Preserv. 5 (1981) 59.

[11] Knudsen J.C., Antanuse H.S., Risbo J., Skibsted L.H., Induction time and kinetics of lactose crystallization of amorphous lactose, infant formula and whole milk powder as studied by isothermal scanning micro-calorimetry, Milchwissenschaft 57 (2002) 543-546.

[12] Miao S., Roos Y.H., Nonenzymatic browning kinetics of a carbohydrate-based lowmoisture food system at temperatures applicable to spray drying, J. Agric. Food Chem. 52 (2004) 5250-5237.

[13] Morgan F., Léonil J., Mollé D., Bouhallab S., Non enzymatic lactosylation of bovine $\beta$-lactoglobulin under mild heat treatment leads to structural heterogeneity of the glycoforms, Biochem. Biophys. Res. Com. 236 (1997) 413-417.

[14] Morgan F., Bouhallab S., Mollé D., Henry G., Maubois J.L., Léonil J., Lactolation of $\beta$-lactoglobulin monitored by electrospray ionisation mass spectrometry, Int. Dairy J. 8 (1998) 95-98.

[15] Morgan F., Léonil J., Mollé D., Bouhallab S., Modification of bovine $\beta$-lactoglobulin by glycation in a powdered state or in an aqueous solution: effect on association behavior and protein conformation, J Agric. Food Chem. 47 (1999) 83-91.

[16] Roos Y.H., Jouppila K., Zielasko B., Nonenzymatic browning-induced water plasticization, J. Thermal Anal. 47 (1996) 1437-1450.

[17] Saltmarch M., Labuza T.P., Influence of relative humidity on the physicochemical state of lactose in spray-dried sweet whey powders, J. Food Sci. 45 (1980) 1231-1236, 1242.

[18] Thomas M., Scher J., Desobry S., $\beta$-Lactoglobulin interaction during storage of model whey powders, J. Dairy Sci. 87 (2004) 1158-1166.

[19] Vuataz G., The phase diagram of milk: a new tool for optimising the drying process, Lait 82 (2002) 485-500. 